\title{
AN ELECTIVE COURSE, "GEOINFORMATION TECHNOLOGIES IN BUSINESS": TEN-YEARS OF EDUCATIONAL EXPERIENCE AT THE LOMONOSOV MOSCOW STATE UNIVERSITY BUSINESS SCHOOL
}

\author{
A. N. Pirogov ${ }^{1,2}$ \\ ${ }^{1}$ Racurs, 129366, Moscow, Russia - pirogov@ racurs.ru \\ ${ }^{2}$ Lomonosov Moscow State University Business School, 119324, Moscow, Russia - an.pirogov@gmail.com
}

Commission V

KEY WORDS: Education, Management, Business, Geoinformation technologies

\begin{abstract}
:
The author has been conducting an elective course on geoinformation technologies in business since 2011 at the Lomonosov Moscow State University Business School. More than 250 people became students of the course in the period from 2011 to 2020. The course offers seven basic thematic modules based on training cases in which GIS tools and services are widely used. An education ecosystem was formed to spread knowledge about geoinformation technologies and geodata in business.
\end{abstract}

\section{COURSE OVERVIEW: EVOLUTION, STRUCTURE, AND METHODOLOGY}

\subsection{Lomonosov Moscow State University Business School}

Lomonosov Moscow State University Business School (Lomonosov MSUBS), founded in 1989 in Moscow State University, is one of the oldest business schools in Russia. Lomonosov MSUBS's vision is to be an acknowledged leader in the field of business training, providing international education in Russia and responding to the challenges of the modern business environment. Lomonosov MSUBS successfully integrates the traditional approach with new approaches that view teaching management as a contemporary art of doing business. Having strong connections with the Russian business world, Lomonosov MSUBS also offers tailormade corporate programs.

\subsection{The evolution of the course}

The history of the course is reflected in a change of its name, so in 2011 the course was called "Geographical Aspects of Business." (Pirogov, 2014). The main GIS tools used at that time were Google and Yandex Maps and sometimes desktop QGIS. Most of the training material was the study of geographical patterns and their impacts on business processes. In 2013, with the introduction of the Russian web-based geographic information system GeoMixer, the course changed its name to "Geographic Information Aspects of Business." Up to half of the study time was devoted to working in GIS and studying geospatial data. The limiting factor in the number of students was the number of seats in the computer class. By 2017, the course became fully focused on geographic information technologies and became known as "Geographic Information Technologies in Business." We can say that the transformation of the course took place in parallel with the global changes that have occurred with GIS technologies in the world. The development of GIS and its transition to web platforms does not limit us with the capacity of a computer class and even the power of computing facilities now.

\subsection{Education process and methodology}

According to state educational standards, the elective course lasts 36 academic hours, which are divided into eight classes of four hours. Initially, the course was offered for fourth-year students, but due to changes in state standards, the course has been offered to students in the first year of study for the last few years. Of course such changes force us to reconsider approaches to the educational process, to adapt it to different levels of knowledge, experience, and skills. Between 20 and 30 students enrolled in the Bachelor of Management program choose the course annually. In 2019, the course was rated by students at 9 out of 10 and marked as one of the most practical-oriented. The course consists of practical exercises, a test project in small groups, and an exam. For several consecutive years, the students of the course chose GIS industry companies for practice.

The book Thinking about GIS, by Tomlinson Roger (Tomlinson, 2003), contains correct words that passed time verification and were confirmed by many business practices: "No GIS can be a success without the right people involved. A real-World GIS is actually a complex system of interrelated parts, and at the center of this system is a smart person who understands the whole." Years of communication with managers have shown the author that managers are very similar to geographers in the structure of knowledge (Pirogov, 2018). They comprehend a large amount of diverse educational material, from sociology to taxation during the training. They are able to build interdisciplinary communications and are open to knowledge of the real world, with all the variety of business processes in it. These are precisely those people who decide how the introduction of certain technologies will help increase the efficiency of business processes in the organization. It is worth noting that, unfortunately, textbooks on marketing, advertising, and management rarely mention the capabilities of GIS technologies. An analysis of the subjects studied by students was made, and interdisciplinary relations with the course were determined. The greatest connections of the course are identified with such disciplines as marketing, logistics, advertising, and regional economics. Management is a very "living" profession, requiring constant updating of knowledge and used tools. Therefore, annually the course is updated 
according to the latest achievements in both the GIS field and management.

The teaching of any information technology, not for programmers, is faced with a number of well-known problems. The greatest difficulties arise with students of the first year of study, when many skills have not been formed yet and professional knowledge have not been obtained. Despite the widespread use of modern means of communication by young people, working with even simple applications can cause difficulties for them. This forces us to devote more time for preparing instructions for the tools and services used by GIS, preparing training data, and also revising the training methodology, using group work more than individual.

A feature of the Lomonosov MSUBS adopted training approaches is the maximum orientation toward practical training. Mastering the topics of the course is impossible without understanding the basic theoretical elements of geospatial analysis. The study is based on solving a series of business cases. Each business case includes a description of the real business process, data set, spatial analysis methods, and GIS tools. Two types of business cases are used for the course. The first type allows one, in practice, to get acquainted with the most popular methods of geospatial analysis in business. The second type comprises the cases offered by the partners of the university, which are distinguished by industry and territorial specifics.

Throughout the course, students work in small groups or individually on a test project. Such a project may be related to the theme of the graduation project in one of the compulsory subjects that students prepare at the end of the school year. Often students choose the subject of a credit project based on their interests in management

\subsection{Internship}

Lomonosov MSUBS pays great attention to the acquisition of practical skills and immersion in the business environment. Therefore, after the second year of study, students undergo internships at partner companies of the university. Students undergo a monthly internship at GIS companies for several consecutive years, not only observing work from the inside, but also doing research. So, during an internship at HERE Technologies Rus, students prepared a study of the Russian GIS market in the interests of the development of the company. For Racurs Company, students appreciated the possibility of using photogrammetric software developed by the company in cloud services.

\subsection{Invited experts}

A very important aspect of training is meeting with business representatives and visiting industry companies. Two or three people speak to the students with short stories about GIS every year. Among the invited professionals, there are the founders of GIS companies and the heads of GIS departments of retailers, banks, and logistics companies. For several consecutive years, students have visited ScanEx, a company specializing in the reception and processing of remote sensing data. During the course, representatives of HERE Technologies, MAXAR, X5, Rilos, SmartLoc, and other more or less well-known companies in Russia and abroad presented their companies and technologies.

\section{EXPERTISE, KNOWLEDGE, AND SKILLS}

\subsection{Theory and practice}

The first five years of teaching the course led to the determination of the most relevant basic topics; the most effective methods and tools were selected. The determination of the relevance of the topic was in close collaboration with market companies and recognized industry experts. The course offers seven basic thematic modules for studying:

- Geoinformation technologies. The module demonstrates the place of GIS in the ecosystem of information technologies used by business. It shows that the GIS industry is a full-fledged participant in the global IT business. The experience of conducting the course suggests that every year, the awareness of GIS technologies among students is increasing.

Topics: Geoinformation technologies in business, state management, society.

Subjects: Geographical and geospatial factors. Geospatial data and tools in business decision-making. Geospatial variability. GIS as a part of IT structure. Geoinformation technologies as a business. GIS: possibilities, types, interface, etc. Geoportals.

- Geospatial data: " $80 \%$ of data is geographic" is one of those commonly cited facts. One of the important tasks of this module is to develop students' skills in identifying and analyzing the spatial and geographical aspects of corporate data.

Topic: Geodata.

Subjects: Sources, licenses, formats, geocoding, etc.

- Geospatial analysis methods: Mastering geoanalysis methods, even the simplest ones, significantly increases the possibility of their use in subsequent professional activities among students. Feedback received from graduates proves the effectiveness of this approach.

Topic: Geospatial analysis

Subjects: Methods of geospatial analysis. Artificial intelligence and big data.

- Geomarketing: The most demanded module among students, which has maximum connections with the subjects studied in the specialty of management.

Topic: Geomarketing

Subjects: Geomarketing analysis, services, GIS and IT tools. Huff model. Geospatial intelligence.

- Navigation: This is also a relevant module for students. Navigation and geolocation technologies penetrate deeply into many aspects of everyday life and business process.

Topic: Navigation

Subjects: Indoor and outdoor navigation. Location-based services. Geotargeting. Personal data and location security. GNSS: Services, tools, traffic control.

- Web-geomarketing: The up-to-date module lies at the junction of geomarketing and web analytics. Almost every business has its own virtual storefront on the internet, and the volume of advertising on the web is growing from year to year. Being able to analyze the "space" of the internet and its users is becoming an important part of management.

Topisc: Web-geomarketing, SEO

Subjects: Geoanalytics tools in web marketing. Influencing of social-demographic and natural-climatic factors on web searching. Big data. SEO.

- Territory management and urban planning: This module includes topics of geographical aspects of doing business, including revealing the concepts of cadastre, territorial development, and issues of social and environmental responsibility.

Topics: Territory management, urban planning

Subjects: Cadastre, spatial development, planning. 


\subsection{Interdisciplinary links and training cases examples}

Growth of business demand in GIS solutions leads to an increase in interdisciplinary links between management, geography and GIS. The author uses such links as a course basis

\begin{tabular}{|c|c|c|}
\hline Training cases & Interdisciplinary links & Cases description \\
\hline $\begin{array}{l}\text { "Umbrellas" } \\
\text { "Freight traffic" }\end{array}$ & $\begin{array}{l}\text { Regional Economics, Economic and } \\
\text { Geographic Aspects of Doing } \\
\text { Business, Transportation } \\
\text { Infrastructure Management and City } \\
\text { Logistics }\end{array}$ & $\begin{array}{l}\text { A set of training geographical cases on natural and climatic } \\
\text { effects in business. } \\
\text { The "umbrellas" task is based on real sales data of a retail chain } \\
\text { located in two neighboring towns divided by mountains. The } \\
\text { sales difference is caused by weather elements. } \\
\text { The "freight traffic" is based on real freight handling data in } \\
\text { different towns located in different nature conditions. } \\
\text { The EverGIS online is used as a geovisualization system. The } \\
\text { used data are provided by the business partners. }\end{array}$ \\
\hline $\begin{array}{l}\text { "Aluminum fluoride } \\
\text { plant" }\end{array}$ & $\begin{array}{l}\text { Macroeconomics, Economic and } \\
\text { Geographic Aspects of Doing } \\
\text { Business, Strategic Management, } \\
\text { Operations Management, } \\
\text { Fundamentals of Industrial } \\
\text { Economics, International Business, } \\
\text { Supply Chain Management, etc. }\end{array}$ & $\begin{array}{l}\text { The training case demonstrates an operational management and } \\
\text { supply chain logistic of an industrial plant. } \\
\text { The EverGIS online is used as a geovisualization system. The } \\
\text { used data are provided by the business partners and open } \\
\text { sources. }\end{array}$ \\
\hline station & $\begin{array}{l}\text { Marketing, Marketing Research, } \\
\text { Strategic Management, } \\
\text { Fundamentals of Business Model } \\
\text { Construction, etc. }\end{array}$ & $\begin{array}{l}\text { The training case emulates an urban filling station chain } \\
\text { management. The case includes real location, demographics, } \\
\text { traffic, competitive environment, and other data that allow one } \\
\text { to make a comprehensive geospatial analysis and to offer a } \\
\text { management decision. } \\
\text { The EverGIS online is used as a geoanalytical system. The used } \\
\text { data are provided by the business partners and open sources. }\end{array}$ \\
\hline $\begin{array}{l}\text { "Web-Geomarketing } \\
\text { and GeoSEO" }\end{array}$ & $\begin{array}{lrr}\text { Marketing, } & \text { Internet } & \text { Marketing, } \\
\text { Internet } & \text { Business, } & \text { Regional } \\
\text { Economics, Statistics, etc. } & \end{array}$ & $\begin{array}{l}\text { The case shows spatial-temporal diversity of browsing } \\
\text { behavior. } \\
\text { Data sources: Yandex WordStat, GoogleTrends. The EverGIS } \\
\text { online is used as a geoanalytical system. }\end{array}$ \\
\hline $\begin{array}{l}\text { "Geomarketing } \\
\text { Cases" }\end{array}$ & $\begin{array}{l}\text { Marketing, Sales Management, } \\
\text { Microeconomics }\end{array}$ & $\begin{array}{l}\text { A set of geomarketing cases on spatial location of different } \\
\text { types of business (from street retail to see ports). } \\
\text { Used tools: Business navigator service. Sources of data: Google } \\
\text { Maps, YandexMaps, 2GIS, OSM. } \\
\text { The EverGIS online is used as a geoanalytical system. }\end{array}$ \\
\hline $\begin{array}{l}\text { "Territory investment } \\
\text { attractiveness" }\end{array}$ & $\begin{array}{l}\text { Macroeconomics, Branding, Social } \\
\text { and Value Dimensions of Doing } \\
\text { Business, Human } \quad \text { Resource } \\
\text { Management }\end{array}$ & $\begin{array}{l}\text { A set of business cases and business games on economical and } \\
\text { geographical analysis of a territory. } \\
\text { Tools and data: Regional and municipal Russian geoportals and } \\
\text { state services. }\end{array}$ \\
\hline
\end{tabular}

Table 1. The training cases examples.

\subsection{Data sources}

The solution of practical cases is based on a number of geodata taken from different sources:

- Crowdsourcing data: OpenStreetMap, WikiMapia, etc.

- Corporate data: Data provided by the university partners and professional community.

- State data: Open data, state statistics, etc.

The rationale for the use of certain data sources for solving various problems is important. The concept of data reliability is introduced; different types of licenses and restrictions on the use of data are studied. Both vector and raster data types are used in the course and presented in the most common storage formats (.xlsx, .csv, GeoTIFF, .shp, .kml / .kmz). Data preparation is an important and most time-consuming task for a teacher. Despite during development of educational modules and training cases. The table below provides some examples of the training cases and their interdisciplinary connections.
Cases description

A set of training geographical cases on natural and climatic

located in two neighboring towns divided by mountains. The sales difference is caused by weather elements.

"freight traffic" is based on real freight handling data in The EverGIS online is used as a geovisualization system. The used data are provided by the business partners.

ining case demonstrates an operational management and The EverGIS online is used as a geovisualization system. The used data are provided by the business partners and open sources.

The training case emulates an urban filling station chain traffic, competitive environment, and other data that allow one to make a comprehensive geospatial analysis and to offer a agement decision.

The EverGIS online is used as a geoanalytical system. The used The case shows spatial-temporal diversity of browsing nior.

Data sources: Yandex WordStat, GoogleTrends. The EverGIS A set of geomarketing cases on spatial location of different Ayes of business (from street retail to see ports).

Maps, YandexMaps, 2GIS, OSM.

A set of business cases and business games on economical and

the abundance of data, their formats, type, coding, and structure can often not be used in the educational process without prior preparation. Source data processing is carried out mainly in QGIS.

\subsection{GeoInformation systems}

The history of the course is the history of the development of GIS tools over the past ten years. For the first two years, the course was based on the use of cartographic web services, such as Google or Yandex Maps, and Google Earth. It was decided to completely abandon the use of desktop GIS. The above services could not provide all the objectives of the course; as a result, a search was started for software that would satisfy the needs of the educational process. The requirements for such a software solution were formulated: 
- Web browser engine: online and offline access, ease of use configuration, intuitive interface;

- Multi-user capabilities: Unmetered simultaneous connections, individual login / password, database connection, user administration, network data exchange, networking on maps and layers;

- Data exchange and processing: Export and import of the most common geoformat (GeoTIFF, .shp, .kml / .kmz), attributive and table data processing, WMS | WFS-support, direct URL links on a created map;

- Data creation and analysis: Vectorization tools, buffering, attributing, searching, ranging, etc.

- Base map: World Base Map, OpeenStreetMap, high resolution imagery, SRTM.

- Technical support free of charge for educational purposes.

In the future, we were forced to abandon some of the requirements that seemed redundant for the objectives of the course.

According to the situation for 2013, we considered two software products: ArcGIS online from Esri and GeoMixer from ScanEx (Pirogov, 2014). Testing of ArcGIS online showed that the service would be difficult to use due to the insufficient internet speed available at the university. The Russian company ScanEx proposed its GeoMixer solution, which was installed on a computer-class local network, which ensured fast operation speed. Looking back, one cannot say that the solution was userfriendly. In 2015, we started using Carto. The service turned out to be very user-friendly, and in the following years Carto became our main GIS tool. This was not without incidents. Any web service can suddenly stop working, disrupting the learning process. So in 2017, as a result of a technical failure on Amazon servers (Hern, 2017), the Carto service was unavailable for several classes. There were certain problems with the blocking of Amazon servers by the regulatory authorities of the Russian Federation. It is important to always consider possible technical problems and be prepared to return to the "chalk and blackboard." Since 2020, the course has been translated into the Russian counterpart of Carto, the free EverGIS online service (EverGIS development team, 2019) from Everpoint company.

The table below provides an integrated assessment of the used GIS.

\begin{tabular}{|l|c|c|c|}
\hline Web-GIS & $\begin{array}{c}\text { Free version } \\
\text { functionality } \\
\text { raiting }\end{array}$ & $\begin{array}{c}\text { User- } \\
\text { friendliness } \\
\text { rating }\end{array}$ & $\begin{array}{c}\text { The } \\
\text { author's } \\
\text { rating }\end{array}$ \\
\hline $\begin{array}{l}\text { CartoDB } \\
\text { (the first Carto } \\
\text { version) }\end{array}$ & 3 & 5 & 4 \\
\hline $\begin{array}{l}\text { Carto (current } \\
\text { version) }\end{array}$ & 4 & 2 & 4 \\
\hline GeoMixer & 2 & 1 & 3 \\
\hline ArcGIS online & 3 & 4 & 4 \\
\hline $\begin{array}{l}\text { EverGIS } \\
\text { online }\end{array}$ & 4 & 5 & 5 \\
\hline NextGISweb & 5 & 2 & 3 \\
\hline
\end{tabular}

Table 2. An integrated assessment of the used GIS.

An integrated assessment of the used GIS is based on three key parameters: 1) GIS functionality, which is available in a free web version; 2) user-friendliness, which is evaluated by students during classes; 3 ) a comprehensive author rating reflecting the author's expectation of using the system..

\subsection{GeoInformation services}

During the course, geoportals, mapping, navigation, and other official and crowded GIS services are widely used.
The table below provides examples of the used GIS services and their connections with the thematic modules.

\begin{tabular}{|l|l|}
\hline GIS services & \multicolumn{2}{|c|}{ Thematic modules } \\
\hline $\begin{array}{l}\text { OpenStreetMap, Federal State } \\
\text { Statistic Service, Moscow } \\
\text { Open Data Portal, } \\
\text { MarineTraffic, Flightradar24 }\end{array}$ & $\begin{array}{l}\text { Geospatial } \\
\text { Geospatial analysis } \\
\text { methods }\end{array}$ \\
\hline $\begin{array}{l}\text { Google and Yandex Maps, } \\
\text { OpenStreetMap, HERE OLP, } \\
\text { navigation apps }\end{array}$ & $\begin{array}{l}\text { Navigation, Geospatial } \\
\text { data }\end{array}$ \\
\hline $\begin{array}{l}\text { GoogleTrends, Google } \\
\text { Analytics, Yandex Wordstat }\end{array}$ & $\begin{array}{l}\text { Web-Geomarketing, } \\
\text { GeoSEO }\end{array}$ \\
\hline $\begin{array}{l}\text { SME Business Navigator } \\
\text { (public service) }\end{array}$ & Geomarketing \\
\hline $\begin{array}{l}\text { Russian regional geo and GIS } \\
\text { portals, Russian public } \\
\text { cadastre map }\end{array}$ & $\begin{array}{l}\text { Territory management } \\
\text { and urban planning }\end{array}$ \\
\hline
\end{tabular}

Table 3. GIS services used in educational process (see related links in Appendix).

\section{EDUCATIONAL OUTCOMES AND ENVIRONMENT}

\subsection{Teaching guides}

A methodological aid for the course includes (in paper and electronic forms): A Course Handbook and a GIS Students Guideline. The Course Handbook is a textbook updated every year including theoretical and practical parts, useful links, references, examples, etc. The GIS Students Guideline includes a set of step-by-step instructions in the use of various web GIS with adapted training tasks. This set allows, in the case of limited access to the main educational GIS, a switch to using other free web-GIS.

\subsection{Students feedback}

As stated above, the course was rated by students (2019) at 9 out of 10 and marked as one of the most practical-oriented. An initial survey of students shows that the course is chosen because: 1) information technology mentioned in the name of the course; 2) geography in the name of the course; 3) curiosity about the topic. Only 3-4 out of 10 students marked in the initial course survey that they know about GIS and related topics, which indicates a rather weak level of GIS use in school education. The final survey shows that 9 out of 10 students will use geoinformation technologies in their future professional activities. Communication with graduates does not give such an optimistic scenario for the use of GIS. Only about 20\% of graduates (out of 90 interviewed) use GIS in their professional activities. Only 5 graduates (out of 120) asked the author for advice in choosing GIS systems for companies in which they already work. 2 graduates work in IT companies whose profile is related to geographic information technologies. Undoubtedly, this percentage will increase due to new graduates in the last five years as well as the knowledge spreading about GIS in business.

\subsection{Professional community}

Doing a training course generates a large amount of information. These are not only educational tasks, instructions for using the software, and prepared data, but also gathering market news, communicating with experts, creating unique content, collecting literature, etc. In 2014, the author created the Geomarketing and Spatial Analysis group on Facebook, which quickly gained popularity and is currently the most active group on the topic of geomarketing and GIS in business in Russian- 
speaking Facebook. The group consists of 1,700 members, not only from Russia but also from foreign countries. In 2015, the GISGeo.org website was created, which began to accumulate information in Russian about geomarketing, conducting research, and collecting data. Today, the daily audience of the site is $100-150$ visitors; according to thematic requests, the site is at the top of the internet search engines. The site has earned attention as a thematic resource and has been included in the recommended sources of information on the GIS topic for universities and schools. At the moment, GISGeo is a community of market professionals, where contacts are exchanged, employees are searched, discussions of proposed solutions, etc. In addition to online activity, the community held a series of seminars, including the exchange of experience teaching GIS for nonspecialists.

\section{CONCLUDING REMARKS}

The main result of ten years of the course history was not that more than 200 professional managers are familiar with GIS in Russia, but that an ecosystem was formed to spread knowledge. From an educational point of view, an elective course is a subject that allows one to implement the practical knowledge needed by the employer. For the GIS industry, an elective course at a noncore university is an opportunity for more active implementation of geotechnologies from the inside.

PS. COVID-19. The academic year 2020 will be remembered for a long time because half of the classes were held online due to the self-isolation regime in Moscow. The course showed high adaptability to e-learning. More time was needed to complete the training cases and demonstrate the work with the used GIS. This author's experience remains to be explored.

\section{ACKNOWLEDGEMENTS}

The author wish to thank the Lomonosov Moscow State University Business School for support of the course and professional community for useful comments.

\section{REFERENCES}

Pirogov A., 2014. GIS-based education course for bachelor of management program in the Lomonosov Moscow State University Business School. The International Archives of the Photogrammetry, Remote Sensing and Spatial Information Sciences, Volume XL-6, 2014. ISPRS Technical Commission VI Symposium, 19-21 May 2014, Wuhan, China. P. 79-82. 2014.

Tomlinson R., 2003. Thinking About GIS: Geographic Information System Planning for Managers. Esri Press. P. 280.

Pirogov A., 2018. From Geographical Aspects of Business to Geoinformation Technologies in Business. GIM-International. Blogs. 20.12.2018

Hern A., 2017. How did an Amazon glitch leave people literally in the dark? The Guardian. 1 March, 2017.

EverGIS development team. Everpoint open test meet up. https://medium.com/everpoint (24 June 2019).

\section{APPENDIX}

Moscow Government Open Data Portal: https://data.mos.ru/
SME Business Navigator: https://mbn.smbn.ru/st/13 Russian Public Cadaster Map: https://pkk.rosreestr.ru/ Federal State Statistic Service: https://eng.gks.ru/ MarineTraffic service: https://www.marinetraffic.com/ Flightradar24 service: https://www.flightradar24.com/ Google Trends service: https://trends.google.com/ Google Analytics service: https://analytics.google.com/ Yandex Keyword statistics service: https://wordstat.yandex.ru/ 